Jurnal Ilmu Sosial dan Pendidikan (JISIP)

Vol. 6, No. 1 Januari 2022

e-ISSN : 2656-6753, p-ISSN: 2598-9944

DOI: 10.36312/jisip.v6i1.2714/http://ejournal.mandalanursa.org/index.php/JISIP/index

\title{
Kemanusiaan Vs Kapitalisme di Era Pandemi Corona Virus Disease-19 (COVID19): Ekslusifitas Paten Vs Lisensi Wajib
}

\author{
Sheylla Fatizah \\ Mahasiswa Program Magister Ilmu Hukum, Universitas Indonesia
}

\begin{tabular}{l}
\hline \hline Article Info \\
\hline Article history: \\
Received: 14 Desember 2021 \\
Publish: 02 Januari 2022 \\
\end{tabular}

Keywords:

COVID-19 vaccine,

Developed Countries,

Developing Countries

\begin{tabular}{l}
\hline Info Artikel \\
\hline Article history: \\
Diterima: 12 Desember 2021 \\
Publish: 02 Januari 2022
\end{tabular}

Publish: 02 Januari 2022

\begin{abstract}
Virus Disease-19 (COVID-19) began to spread to various parts of the world since December 2019, which was first discovered in Wuhan, China. Of course this has brought great disaster to 216 countries in the world, because no country is immune to this virus and the epidemic has spread to various continents and attacked many aspects of the world community. Distressing conditions like this require the state to play a stronger role by providing better service protection. In addition, conditions like this raise big questions about how countries in the world deal with this. In the midst of the COcVID-19 pandemic, many scientists are racing to quickly find an effective vaccine to fight this virus. An example of one that succeeded is the discovery of Sinovac or called CoronaVac, where this vaccine is the result of research from Sinovac Biotech Co. which is a biopharmaceutical company focused on research, development, manufacture and commercialization of vaccines, and the company is based in Beijing, China. Seeing the COVID-19 pandemic that is increasingly paying attention, especially in developing countries, many countries are pressing for the temporary waiver of COVID-19 vaccine patents during this crisis. The reason is none other than so that production can be accelerated so that it is expected to be able to handle the COVID-19 pandemic. Of course this raises a polemic between developed countries and developing countries where there are two different interests, one country protects its investors and the other one protects its people. From this we can see that COVID-19 leaves a lot of room for its own problems.
\end{abstract}

\begin{tabular}{l}
\hline ABSTRAK \\
\hline Corona Virus Disease-19 (COVID-19) mulai menyebar ke berbagai belahan dunia sejak \\
Desember 2019 yang diketahui pertama kali ditemukan di Wuhan, China. Tentu saja hal \\
ini telah membawa bencana besar bagi 216 negara di dunia, pasalnya tidak ada satu \\
negara pun yang imun terhadap virus ini dan epidemi telah menyebar ke berbagai benua \\
dan menyerang banyak aspek pada masyarakat dunia. Kondisi memperihantinkan \\
seperti ini menuntut negara berperan lebih kuat dengan memberikan proteksi pelayanan \\
yang lebih baik. Selain itu juga, kondisi seperti ini menimbulkan pertanyaan besar \\
tentang bagaimana negara-negara di dunia mengatasi hal ini. Ditengah Pandemi \\
COVID-19 ini banyak ilmuwan berlomba untuk segera menemukan vaksin yang efektif \\
untuk melawan virus ini. Contoh salah satu yang berhasil adalah penemuan Sinovac \\
atau disebut dengan CoronaVac, yang dimana vaksin ini merupakan hasil riset dari \\
Sinovac Biotech Co. yang merupakan perusahaan biofarmasi yang berfokus pada \\
penelitian, pengembangan, pembuatan, dan komersialisasi vaksin, dan perusahaan ini \\
berbasis di Beijing, China. Melihat pandemi COVID-19 yang semakin memperhatikan, \\
terlebih lagi di negara berkembang, banyak negara yang mendesak untuk dilakukannya \\
pengabaian sementara hak paten vaksin COVID-19 dimasa krisis ini. Alasannya tidak \\
lain agar produksi bisa dipercepat sehingga diharapkan dapat menangani pandemi \\
COVID-19. Tentu hal ini menimbulkan polemik diantara negara maju dan negara \\
berkembang dimana ada dua kepentingan yang berbeda, negara yang satu melindungi \\
investornya dan negara yang satu melindungi masyarakatnya. Dari sini dapat kita lihat \\
bahwa COVID-19 banyak menyisakan ruang persoalan tersendiri, Oleh karenanya \\
bagaimana cara hukum bekerja ditengah carut marut situasi ini penting untuk di \\
diskusikan.
\end{tabular}

This is an open access article under the Lisensi Creative Commons AtribusiBerbagiSerupa 4.0 Internasional

\section{Corresponding Author:}

Sheylla Fatizah

Mahasiswa Program Magister Ilmu Hukum, Universitas Indonesia

E-mail: sheylla.fatizah@gmail.com 


\section{PENDAHULUAN}

World Health Organization (WHO) pada 30 Januari 2020 mendeklarasikan Corona Virus Disease-19 (COVID-19) sebagai global emergency. Kemudian pada 12 Maret 2020 WHO meningkatkan statusnya menjadi pandemi, yang berarti bahwa virus ini merupakan epidemi yang sudah menyebar ke seluruh belahan dunia dan menyerang banyak masyarakat dunia. Dalam sejarahnya, WHO pernah mengumkan dua pandemi, diantaranya influenza di tahun 1918 dan influenza H1N1 di tahun 2009. China, sebagai pusat penyebaran pertama virus COVID-19, hingga saat ini terus melaporkan pertumbuhan pasien baru mulai melambat dan sebagian pasien sembuh, namun dunia belum bisa memprediksi kapan berakhirnya pandemi ini. Pandemi COVID-19 yang tidak diantisipasi kedatangannya ini telah mengubah perdagangan global dunia. Kinerja perdagangan tentu saja terganggu dikarenakan supply chain yang terhambat karena dilakukannya penutupan pabrik besar-besaran dan ditutupnya jalur distribusi logistik sejumlah negara guna menyetop penyebaran COVID-19. Banyak negara maju, negara berkembang, maupun negara terbelakang telah mengumumkan keadaan darurat nasional dengan tujuan untuk mengekang atau mencegah wabah yang berkembang, dan seperti yang disarankan oleh WHO menerapkan pembatasan sosial dengan konsekuensi yang signifikan bagi masyarakat dan ekonomi. Khususnya, negara berkembang dan negara kurang berkembang terkena dampak yang tidak proporsional. Kebijakan negara mengenai COVID-19 ini dapat memberikan dampak perubahan ekonomi yang signifikan, karena hampir semua sektor terdampak. Apabila tidak ada peran dari negara di dunia, semua bisnis tidak bisa berjalan dan perekonomian semakin terpuruk.

Vaksinasi adalah senjata dalam mengahadapi pandemi, sehingga menemukan atau bahkan memproduksi vaksin akan menjadi komoditi yang sudah pasti diincar oleh barbagai negara di dunia karena memiliki daya jual tinggi. Tentu saja penemuan semacam ini perlu untuk dilindungi melalui instrumen hukum yang kita kenal dengan perlindungan Hak Kekayaan Intelektual (HKI), yakni melalui paten. Ekslusifitas Vaksin COVID-19 dalam perlindungan HKI bukanlah hal yang dapat dieksploitasi tanpa batas, melainkan sebuah negara dapat hadir sebagai bentuk perlindungan atau tanggung jawab negara melalui penerapan lisensi wajib.

Negara-negara besar yang berusaha menemukan Vaksin COVID-19 diantaranya ada China, Amerika Serikat, Rusia, Australia, Inggris, dan juga Jerman. Penemuan vaksin ini tentu dijadikan ajang lomba dan menjadi langkah awal perang dagang negara besar adi kuasa, hal ini dikarenakan vaksin memiliki nilai ekonomi dan memiliki aspek hukum yang melindunginya sebagai hasil karya intelektual manusia. Proses pengerjaannya tidak mudah dan membutuhkan waktu yang tidak sedikit, dan dilakukan beberapa kali (trial and error) sehingga akhirnya dapat ditemukan formula yang benar-benar dapat mengatasi penyebaran pandemi COVID-19. Sebuah vaksin yang sudah diberikan perlindungan secara hukum, tidak boleh digunakan oleh orang lain tanpa izin dari penemu (Inventor) vaksin tersebut. Pelanggaran atas hak ini akan memberikan sanksi hukum yang jelas.

Pada 2 Oktober 2020 di Jenewa dan dihadapan Dewan Trade-Related Aspects of Intellectual Property Rights (TRIPS) WTO, India dan Afrika Selatan mengajukan proposal agar WTO mengesampingkan penerapan ketentuan tertentu dari Perjanjian TRIPS terkait dengan hak paten selama pandemi. Hal ini dilakukan tidak hanya untuk kepentingan India dan Afrika Selatan saja, melainkan untuk negara berkembang maupun negara miskin lainnya. Penangguhan hak paten ini bertujuan untuk memberikan fasilitas akses yang lebih luas ke teknologi yang diperlukan untuk memproduksi vaksin yang sudah ditemukan. Selain itu juga dengan adanya pembebasan ini, diharapkan produksi lokal menjadi cepat dilaksanakan dan akses luas ke vaksin yang terjangkau dan efektif. Mengingat konteks darurat global saat ini, penting bagi Anggota WTO untuk bekerja sama untuk memastikan bahwa hak kekayaan intelektual, yang dalam konteks ini adalah hak paten, tidak menghalangi akses tepat waktu ke vaksin, obat-obatan atau peningkatan penelitian, pengembangan, ataupun pembuatan yang berkaitan penting untuk memerangi COVID-19. 
Kemudian proposal dari India dan Afrika Selatan ini ditentang keras oleh negara-negara kaya seperti Amerika Serikat, Inggris, serta negara-negara Uni Eropa. Mereka berpendapat bahwa penangguhan hak paten hanya akan menghambat inovasi vaksin COVID-19 di perusahaan farmasi dengan merampas insentif untuk melakukan investasi besar dalam penelitian dan pengembangan vaksin COVID-19 itu sendiri. Tentu saja hal semacam ini akan kontraproduktif dengan upaya menanggulangi Pandemi COVID-19 di dunia. Negara anggota WTO setuju bahwa ada kebutuhan yang sangat mendesak atas vaksin ini yang harus di distribusikan secara cepat dan adil, namun mereka berpandangan bahwa pengabaian hak paten bukanlah cara terbaik untuk mencapai hal tersebut.

Penemuan vaksin memang merupakan hasil daripada ujian sains, tetapi membuatnya dapat diakses dan dapat dijangkau juga akan menjadi ujian kemanusiaan untuk masyarakat dunia kapitalis saat ini. Keberhasilan penemuan vaksin COVID-19 merupakan penemuan yang sangat bermanfaat untuk memulihkan dunia internasional, terlebih untuk kepentingan tiap-tiap anggota bahwa pandemi ini harus dikendalikan sedini mungkin dengan menyediakan akses vaksin yang adil, terjangkau dan tepat waktu. Lantas bagaimana aspek hukum di bidang perlindungan Kekayaan Intelektual dan tanggung jawab negara dalam menjamin kesejahteraan umum, bagaimana setiap negara memastikan bahwa seluruh masyarakatnya dapat menggunakan vaksin COVID-19 ini. Tentu saja peran negara sangat dibutuhkan untuk hadir dan melakukan tindakan intervensi dalam kebijakan internasional yang mungkin saja merugikan negaranya.

\section{HASIL DAN PEMBAHASAN}

\subsection{Landasan Filosofis Perlindungan Vaksin COVID-19}

Dalam aspek filosofis, konsep dan rezim HKI ini baru muncul sekitar Abad ke-18. Pada masa itu terdapat pandangan John Locke mengenai teori Hukum Alam. Ia menggambarkan keadaan alam dimana benda-benda yang ada di alam adalah karunia Tuhan, tetapi tidak bisa dinikmati begitu saja melainkan seseorang harus mencari cara agar mengubah benda-benda tadi menjadi milik pribadi dengan menambah nilai pada benda tersebut. Sangat penting untuk memberikan penghargaan terhadap suatu "pengorbanan" dalam menemukan sesuatu yang berasal dari alam, berupa suatu hak milik. Sesuatu yang dihasilkan melalui proses atau kegiatan manusia seringkali memberikan dampak yang bernilai bagi masyarakat, sehingga nilai sosial tadi menjadi dasar pemberian penghargaan terhadap orang tersebut. Locke menyarankan supaya hak ekonomi diberikan perlindungan dalam hak milik, sehingga dapat diterjemahkan sebagai pendorong agar si pencipta bersedia untuk membuka karyanya tersebut. Tujuannya dibukanya karya ciptanya tadi adalah untuk memicu penciptaan ide-ide yang baru lagi, oleh kerena itu, melalui keuntungan ekonomi yang didapatkan, seseorang bisa didorong untuk menemukan dan menjual temuannya tadi sehingga bermanfaat untuk masyarakat.

Berkaitan dengan penemuan Vaksin COVID-19 ditengah pandemi ini, tentu saja sudah seharusnya mendapatkan perlindungan atas penemuan tersebut, misalnya melalui hak paten. Paten hadir sejak abad XIV dan XV di negara Italia dan Inggris, namun pada saat itu pemberian hak paten bukan karena adanya suatu invensi namun ditujukan untuk menarik para ahli luar negeri agar menetap di negara yang mengundangnya tadi dan mengembangkan keahliannya di negara pengundang. Tujuannya tidak lain adalah untuk memajukan penduduk di negara tersebut, sehingga pada masa itu paten ini semacam "izin menetap". Sehingga dapat kita artikan bahwa keuntungan atau royalti yang didapatkan para ahli tadi adalah izin tinggal, sedangkan yang harus ia lakukan adalah berkontribusi mengembangkan keahliannya di negara tersebut untuk kepentingan rakyat disana. Kemudian pada abad XVI muncul mengenai aturan pemberian hak paten terhadap hasil penemuan (uitvinding) di negara-negara Venesia, Belanda, Inggris, Australia, Jerman, dan sebagainya. Sejarah historisnya, pengaturan paten dimuat kedalam suatu aturan atau undang-undang HKI pertama kali di Venice, Italia sekitar tahun 1470. Nama-nama seperti 
Caxton, Galileo, dan Guttenberg tercatat dalam sejarah sebagai penemu yang ada dalam kurun waktu tersebut dan memiliki hak monopoli atas penemuan yang mereka lakukan. Lantas aturan mengenai paten diadopsi oleh kerajaan Inggris pada zaman TUDOR sekitar tahun 1500-an dan kemudian lahirlah aturan tentang paten pertama di Inggris yakni Statute Monopolies (1632). Sedangkan Amerika pada saat itu memiliki undang-undang tentang paten pada tahun 1791. Seiring dengan perkembangan teknologi dan perkembangan waktu di abad XX, sifat daripada pemberian paten tidak lagi sebagai suatu hadiah, melainkan pemberian hak dikarenakan atas suatu temuan seseorang. Perkembangan ini merambat di negara-negara Amerika Utara dan Amerika Selatan. Dilanjutkan dengan Amerika Serikat membentuk undang-undang paten yang dengan tegas mengyatakan mengubah sifat pemberian hak tersebut. Dilanjutkan juga oleh negara seperti Inggris, Rusia, Belanda, Prancis, hingga kini dalam abad XX aturan terkait paten hampir meliputi semua negara di dunia, tidak terkecuali kawasan Asia.

Namun perlu diperhatikan bahwa, Locke melanjutkan pandangannya tentang kepemilikan atas sesuatu dengan berlebihan justru akan merugikan kepentingan orang lain sehingga dapat dikatakan bertentangan dengan Hukum Alam. Hak milik bisa diberikan terhadap sesuatu apabila memenuhi syarat "enough and as good left in common for others". Artinya bahwa ketika suatu ide bisa menghasilkan sesuatu yang memberikan manfaat dan dibutuhkan oleh orang banyak, maka ide tadi tidak bisa diberikan HKI, karena apabila diberikan maka akan memberikan dampak negatif bagi kesejahteraan masyarakat. misalnya pilar penyangga bangunan dalam arsitektur tidak bisa diberikan perlindungan HKI karena semua orang di dunia pasti menggunakannya untuk membangun sebuah bangunan atau dalam kata lain merupakan kondimen penting dalam dunia arsitektur. Sehingga, suatu perlindungan tidak bisa diberikan terhadap ide yang bersifat umum melainkan sesuatu itu harus memiliki karakteristik atau ciri tersendiri diantar yang lainnya.

Dari penjelasan Locke mengenai pembatasan terhadap pemberian HKI, pada masa sekarang ini kaitannya sangat erat dengan penemuan Vaksin COVID-19 yang begitu dibutuhkan oleh masyarakat luas guna memberhentikan penyebaran virus yang sudah memakan banyak korban dari berbagai belahan dunia. Seperti yang sudah dijelaskan sebelumnya bahwa terdapat keinginan dari negara berkembang seperti Afrika Selatan dan India untuk dilakukannya pengabaian sementara hak paten terhadap vaksin COVID-19 guna mempermudah akses terhadap vaksin, sehingga dapat segera di produksi di masingmasing negara berkembang yang tingkat penyebaran virusnya tinggi. Tentu saja hal ini tidak langsung disetujui begitu saja oleh para Inventor dari Vaksin COVID-19 ini, banyak aspek yang harus diperhatikan, mulai dari pendanaan untuk melakukan penelitian yang tidak mudah dan sebentar, serta kepentingan dari para investor yang sudah berkontribusi dalam pendanaan penelitian tersebut, terlebih setiap negara yang menjadi anggota WTO sudah sepakat untuk tunduk terhadap aturan Trade-Related Aspects of Intellectual Property Rights (TRIPS) yang begitu menghormati hak kekayaan intelektual. sehingga dapat kita lihat disini terdapat pertentangan antara kepentingan negara maju yang mementingkan para investornya dan negara berkembang yang mementingkan masyarakatnya dalam memperjuangkan pemenuhan Vaksin COVID-19. Lantas bagaimanakah hukum akan memandang dua kepentingan ini akan dibahas pada poin berikut.

\subsection{Kehadiran Negara dalam Pemenuhan Vaksin COVID-19}

Isu terkait dengan Hak Kekayaan Intelektual (HKI) saat ini mulai menjadi perhatian negara-negara di dunia, hal ini dipicu karena adanya permintaan dari negara berkembang yakni India dan Afrika Selatan untuk sementara waktu dilakukan pengabaian sementara hak paten pada Vaksin COVID-19. Menurut mereka pandemi COVID-19 memerlukan tanggapan global yang didasarkan pada persatuan, solidaritas, dan kerja sama multilateral. Sehingga terdapat keadaan luar biasa yang membenarkan untuk mengabaian dari kewajiban perjanjian Trade-Related Aspects of Intellectual Property Rights (TRIPS) terkait dengan paten vaksin COVID-19. Segala upaya dilakukan oleh tiap negara, 
khususnya negara berkembang dan negara miskin untuk mengahadapi COVID-19, memang vaksin bukanlah merupakan jalan keluar untuk mengatasi pandemi, namun upaya dalam hal mendatangkan vaksin merupakan upaya terbaik tiap-tiap negara untuk memberikan jaminan kesehatan dan melindungi masyarakatnya.

Berbeda pandangan dengan negara maju, mereka berpendapat bahwa perebutan vaksin secara global justru akan berisiko menambah panjang pandemi, justru dalam hal ini negara maju selalu menegaskan akan membagikan vaksin kepada negara miskin secara adil. Selain itu mereka juga berpendapat bahwa permintaan perilisan informasi terkait dengan vaksin COVID-19 ini tidak akan meningkatkan pasokan dalam jangka pendek, hal ini disebabkan pembuatan vaksin itu sangat rumit sehingga tidak bisa serta merta mendapatkan informasi terkait vaksin kemudian dapat dengan mudah diproduksi dalam jumlah besar begitu saja. Selain itu, pada bulan Maret dan April 2021 banyak sikap kontra atas proposal dari negara berkembang tersebut, yakni tidak lain dari perusahaan farmasi negara maju misalnya Biotechnology Innovation Organization (BIO), Pharmaceutical Research and Manufacturers of America (PhRMA), lima belas organisasi industri dan perdagangan (termasuk BIO and PhRMA), empat organisasi kekayaan intelektual. Thom Tillis, selaku sub komite Kekayaan Intelektual mengirimka surat terpisah kepada Administrasi Biden, anggota Kongres, dan pejabat di Kantor Paten dan Hak Cipta, agar menentang proposal pengabaian HKI COVID-19.

Tentu saja pandemi COVID-19 tidak mungkin dibiarkan begitu saja oleh negaranegara di dunia, pasalnya dengan virus ini populasi dunia mungkin saja bisa habis. Francis Fukumaya dalam Adi Fahrudin, Ph.D menerangkan bahwa suatu negara yang mengalami penyebaran penyakit maupun tingkat kemiskinan yang terus bertahan dan bertambah bukanlah hal yang ikhwal berdiri sendiri, melainkan gejala politik dimana negara yang memiliki peran sebagai institusi terpenting dalam masyarakat dianggap gagal melaksanakan perannya, dan bahwa kegagalan negara tersebut bisa menjadikan ancaman terbesar bagi umat manusia. Fungsi negara itu sendiri menurut Francis, memiliki tiga fungsi penting yakni;

a. Fungsi minimal, dalam hal ini, negara haruslah berupaya untuk menyediakan kebutuhan publik. Misalnya memenuhi kebutuhan pertahanan, hukum, ketertiban, dan kesehatan masyarakat.

b. Fungsi menengah, negara dalam hal ini dapat mengatur mengenai monopoli atau kepemilikan, menangani persoalan eksternal seperti pendidikan maupun lingkungan.

c. Fungsi aktivis, negara berperan untuk menyusun regulasi dalam negerinya.

Pemenuhan vaksin COVID-19 merupakan tanggung jawab negara untuk memenuhi fungsinya sebagaimana yang telah dijelaskan diatas. Namun tanggung jawab itu tidak akan mudah untuk dilakukan apabila vaksin COVID-19 telah dilindungi oleh HKI, hal ini disebabkan karena HKI memberikan hak ekslusif kepada pemegang hak tersebut atau dalam hal ini adalah penemu Vaksin COVID-19. Dengan dilindunginya Vaksin COVID19 oleh instrumen hukum yang ada, pemegang hak dapat mengontrol pembuatan, penjualan, penggunaan, pengimporan, penyewaan, penyediaan kepada pihak lain melalui izin dari pemegang hak. Selain itu juga, dalam hal Vaksin COVID-19 sudah mendapatkan perlindungan hukum paten, maka ini akan menjadi barrier to entries dalam industri farmasi, dimana perusahaan penemu dapat memberikan batasan ruang gerak perusahaan farmasi lainnya untuk berinovasi karena harus menunggu lisensi vaksin yang memiliki paten yang sudah habis atau sudah selesai (off-patent), yang sebagaimana kita ketahui bahwa ini memerlukan waktu yang lama. Mengingat proses penelitian dan inovasi Vaksin COVID-19 ini tidak mudah dan membutuhkan waktu yang panjang, diperlukanlah sebuah kolaborasi dari berbagi pihak, misalnya akademisi dan lembaga penelitian dengan skema kerja sama penelitian produk (join research), kerja sama pengembangan produk (joint development), transfer teknologi (technology transfer), dan yang paling penting adalah dukungan dari pemerintah. 
United State Trade Representative (USTR) Katherine Tai mengatakan bahwa memang masih ada kesenjangan yang mengaga antara negara maju dan negara berkembang dalam hal pengaksesan ke obat-obatan, yang dalam hal ini vaksin COVID-19, dan perlu diingat bahwa ini bukan hanya tantangan untuk pemerintah melainkan juga tantangan untuk industri yang bertanggung jawab atas pengembangan dan pembuatan Vaksin COVID-19, ia juga mengatakan bahwa dunia harus belajar dari epidemi HIV/AIDS, dimana pada saat itu tindakan pembatasan terhadap akses ke obat-obatan berkontribusi pada penderitaan dan kematian yang tidak perlu.

Namun, perlu diketahui bahwa hadirnya sebuah negara dalam memenuhi kebutuhan Vaksin COVID-19 ditengah kondisi genting seperti ini dapat mengesampingkan sebuah hak ekslusif sebuah kekayaan intelektual yang sudah memperoleh perlindungan hukum. Tindakan yang dapat dilakukan oleh suatu negara ditengah situasi pandemi global seperti ini adalah dengan menerapkan lisensi wajib, artinya bahwa pemerintah suatu negara dapat mengeluarkan izin kepada orang atau suatu perusahaan untuk menghasilkan produk yang telah dilindungi dengan paten tanpa persetujuan pemegang paten yang bersangkutan.

Adanya aturan mengenai lisensi wajib ini karena disadari ada kelemahan dalam pemberian perlindungan paten karena tidak luput dari pemberian dampak negatif terhadap masyarakat, terutama kepada masyarakat negara-negara berkembang. Misalnya dengan adanya paten obat yang sangat dibutuhkan oleh masyarakat banyak akan menyulitkan akses dalam mendapatkan obat-obatan yang diperlukan. Oleh karena itu pasal mengenai lisensi wajib ini hadir di dalam TRIPS. Hal ini sejalan dengan Pasal 8 Perjanjian TRIPS yang membenarkan suatu negara untuk menetapkan atau mengubah hukum dan peraturan perundang-undangan mereka guna kepentingan kesehatan masyarakat. Namun, perlu di catat bahwa apabila suatu negara mengubah peraturan nasionalnya demi memungkinkan pemerintah negara tersebut untuk memberikan lisensi wajib kepada orang atau perusahaan nasional di negaranya, hal ini tidak luput dari penentangan keras dan keberatan dari pemegang paten yang umumnya adalah perusahaan farmasi yang ada di negara maju. Adapun contoh negara yang telah menemukan vaksin COVID-19 adalah farmasi asal China yakni Vaksin Sinovac (CoronaVac); Vaksin Novavax dari Amerika Serikat; Vaksin AstraZeneca-Oxford; Vaksin Pfizer-BioNTech; dan Vaksin COVAX. Selain penentangan keras dari negara maju, pemanfaatan lisensi wajib juga harus menghadapi tantangan sulitnya perusahaan di negara berkembang untuk memproduksi vaksin yang diperlukan masyarakat mengingat metode pembuatan Vaksin COVID-19 yang begitu kompleks serta kemampuan kapital negara berkembang itu sendiri. Terlebih pelaksanaan dari lisensi wajib harus dilakukan untuk memenuhi kebutuhan domestik dalam negeri negara tersebut, yang dalam hal ini pihak yang bersangkutan tidak dapat melakukan ekspor kepada negara berkembang atau negara miskin yang memang belum mampu melakukan produksi sendiri. Artinya bahwa Vaksin COVID-19 akhirnya mengharuskan negara itu untuk mengimpor dari perusahaan farmasi yang memegang paten. Kemudian masalah yang ada dalam pengimplementasian lisensi wajib menjadi perhatian bagi Dewan TRIPS sehingga pada tahun 2003 dikeluarkanlah Keputusan Dewan Umum TRIPS mengenai paragraph 6 system. Sehingga dengan adanya keputusan ini memberikan kemungkinan kepada suatu negara berkembang untuk melakukan ekspor atau mengimpor Vaksin COVID-19 yang diproduksi berdasarkan lisensi wajib.

Perlu disadari bahwa ada kebutuhan mendesak untuk meningkatkan upaya negara untuk mendistribusikan Vaksin COVID-19 secara cepat, dengan aman dan efektif sehingga dapat membatasi dampak pandemi pada orang, ekonomi, dan masyarakat. Dengan demikian, atas nama kesehatan dan keselamatan masyarakat tiap negara, maka negara dapat melakukan intervensi melalui lisensi wajib apabila Vaksin COVID-19 sudah mendapatkan perlindungan hukum, dengan pertimbangan yang telah diuraikan diatas.

Sampai dengan tulisan ini dibuat, Direktur Jenderal World Health Organization (WHO) Dr. Tedros Adhanom Ghebreyesus memberikan apresiasi kepada komitmen 
pemerintahan Amerika Serikat yakni Joe Biden dan Wakil Presiden Kamala Harris untuk mendukung pengabaian sementara atas perlindungan kekayaan intelektual Vaksin COVID19 sebagai langkah yang berani untuk mengakhiri pandemi secepatnya. United State Trade Representative (USTR) Katherine Tai merilis pernyataan bahwa pengabaian sementara hak kekayaan intelektual Vaksin COVID-19 sudah mendapat dukungan dari pemerintah Amerika Serikat yakni Biden-Harris, hal ini dikarenakan apa yang dihadapi dunia pada saat sekarang ini merupakan krisis kesehatan global dan keadaan luar biasa sehingga membutuhkan tindakan yang luar biasa pula.

\subsection{Instrumen Hukum Vaksin COVID-19: Ekslusifitas Paten Vs Lisensi Wajib}

Kekayaan intelektual (intellectual property) merupakan sebuah ciptaan yang dihasilakan melalui kemampuan intelektual manusia (creation of mind) yang kemudian diwujudkan dalam suatu bentuk, misalnya karya tulis, karya bersifat artistik, simbol, gambar, maupun desain yang kemudian dimanfaatkan untuk kepentingan perdagangan. Creation of mind ini ditegaskan pula dalam Pasal 2 paragraf viii Agreement Establishing the World Intellectual Property Organization, yakni;

a. Karya tulisan, seni, beserta karya yang berada dalam bidang ilmu pengetahuan;

b. Penampilan yang disajikan oleh artis melalui media rekaman maupun penyiaran;

c. Ciptaan yang baru di berbagai bidang;

d. Penemuan untuk pertama kali di bidang ilmu pengetahuan;

e. Desain industri;

f. Merek maupun julukan komersial;

g. Perlindungan terhadap persaingan curang (unfair competition);

Adapun Trade-Related Aspects of Intellectual Property Rights (TRIPS) tidak memberikan definisi secara gamblang apa yang dimaksud dengan Hak Kekayaan Intelektual (HKI), namun istilah HKI dapat kita lihat pada preambul Perjanjian TRIPS dimana tertulis: "Desiring to reduce distortions and impediments to international trade, and taking into account the need to promote effective and adequate protection of intellectual property rights, and to ensure that measures and procedures to enforce intellectual property rights do not themselves become barriers to legitimate trade."

Dari uraian-uraian tersebut dapat kita simpulkan bahwa HKI merupakan hak yang timbul dari hasil pemikiran atau intelektual manusia, yang kemudian pemikirannya itu dituangkan dalam sebuah wujud yang nyata, entah itu dalam bentuk invensi, kreasi, ciptaan, desain, yang kemudian wujud nyata tadi memiliki nilai ekonomi dan memiliki manfaat bagi kehidupan manusia sehingga akhirnya dilindungi oleh hukum. Ada dua alasan utama mengapa negara menciptakan undang-undang untuk melindungi kekayaan intelektual seseorang, yakni yang pertama untuk memberikan ekspresi hukum hak moral dan ekonomi bagi pencipta, serta memberikan hak publik dalam mengakses ciptaannya tersebut, yang kedua adalah untuk mempromosikan kreativitas untuk mendorong perdagangan yang adil dan menciptakan perdagangan yang berkontribusi pada pembangunan ekonomi dan sosial. Perlu dipahami bahwa seseorang bebas untuk memilih mengajukan permohonan untuk melindungi karyanya atau tidak. Hak ekslusif yang diberikan negara kepada penemu atau pemegang karya intelektual adalah didasarkan pada bentuk penghargaan atas hasil kekayaan intelektual seseorang tersebut. Adapun tujuan diberikannya perlindungan HKI adalah;

a. Memberikan penghargaan atas penemuan yang dihasilkan melalui usaha dan kerja keras penemu.

b. Mempromosikan publikasi invensi dalam bentuk dokumen yang bisa dilihat oleh masyarakat.

c. Merangsang adanya alih informasi melalui kekayaan intelektual, misalnya melakukan alih teknologi untuk kekayaan intelektual yang dilindungi paten.

d. Memberikan perlindungan hukum apabila nantinya karya si penemu ditiru oleh orang lain. 
TRIPS dalam perkembangannya memberikan perlindungan paten yang cukup ketat terhadap suatu invensi hasil pemikiran manusia, hal ini tentu saja sangat diperlukan guna melindungi pemilik hak paten. Sebagaimana yang kita ketahui bahwa terdapat keberhasilan penemuan Vaksin COVID-19 ditengah perluasan penyebaran virus COVID19 di masyarakat dunia sampai harus dilakukan pembatasan sosial berskala besar yang mengganggu ruang gerak masyarakat untuk beraktivitas. Tentu saja penemuan Vaksin COVID19 ini tidak boleh dipandang hanya dari aspek ekonomi, tetapi juga harus dipandang dari aspek sosial, dikarenakan penemuan ini adalah upaya dalam pemulihan kesehatan masyarakat (public health recovery) namun juga tidak mengabaikan apa yang sudah diupayakan oleh inventor atas hak ekonomi dan hak moral yang melekat pada penemuan Vaksin COVID-19. Dengan dilindunginya Vaksin COVID-19 yang sudah ditemukan oleh inventornya maka akan memberikan hak monopoli dan memberikan insentif untuk secara berkelanjutan juga mengalokasikan dana terhadap riset dan pengembangan terhadap temuannya itu. Selain itu juga, dengan dilindunginya secara hukum penemuan vaksin COVID-19 hasil penemuan inventor akan menciptakan sustainability, yang hingga pada akhirnya menciptakan competitive advantage bagi perusahaan ataupun organisasi yang terlibat di dalamnya. Vaksin COVID-19 merupakan komoditi yang harus dilindungi melalui instrumen hukum, sebab vaksin dihasilkan oleh riset yang panjang oleh seorang peneliti sehingga perlu untuk diberikan penghargaan. Peneliti dalam melakukan riset vaksin COVID-19 ini tentu telah mengupayakan waktu, pikiran, tenaga, dan biaya yang tidak sedikit. Selain itu juga, perlindungan vaksin melalui instrumen hukum dapat mengontrol penggunaan maupun penjualan vaksin tersebut.

Namun seiring dengan berkembangnya keadaan dunia, perlindungan paten tidak luput dari pemberian dampak negatif kepada masyarakat suatu negara terutama negara berkembang, hal ini disebabkan karena masyarakat mendapatkan kesulitan dalam mengakses apa yang telah dipatenkan tersebut, dalam hal ini Vaksin COVID-19. TRIPS memberikan kemungkinan untuk mengabaikan hak ekslusif dalam perlindungan HKI, artinya bahwa HKI dapat dikecualikan dalam hal tertentu, karena ekslusifitas dalam HKI merupakan hak yang ada batasnya. Salah satu wujud daripada pembatasan hak tersebut adalah adanya aturan mengenai lisensi wajib (compulsory licence). Lisensi wajib merupakan pemberian izin dari pemerintah suatu negara kepada suatu perusahaan atau kepada seseorang untuk menghasilkan produk yang dipatenkan tanpa persetujuan dari pemilik atau pemegang paten.

Alasan pentingnya lisensi wajib paten, yang dalam hal ini Vaksin COVID-19 adalah untuk mencegah penyalahgunaan hak pemegang paten yang mungkin saja dapat merugikan masyarakat, memenuhi kebutuhan mendesak suatu negara atau situasi dan kondisi yang ekstrem. Dalam hal lisensi wajib, hak individual dari seorang pemegang paten, tidak boleh dikurangi untuk dimanfaatkan oleh individu yang lainnya, melainkan hanya dapat dikurangi untuk dimanfaatkan oleh kepentingan sosial dan kolektif. Hal ini sejalan dengan Pasal 7 TRIPS dengan memperhatikan Paragraf 4 Preambul TRIPS yang dimana keseimbangan antara hak dan kewajiban tidak bisa diperoleh melalui pengurangan hak pemegang paten tanpa adanya kepentingan masyarakat luas atau kepentingan masyarakat secara kolektif. Artinya bahwa penerapan lisensi wajib harus dilakukan dengan alasan khusus, antara lain;

e. Dilakukan agar mencegah penyalahgunaan hak pemegang paten yang diakibatkan dari pelaksanaan hak ekslusif lainnya.

f. Dilakukan agar mengurangi ketidak cukupan pelaksanaan invensi yang di patenkan

g. Dilakukan untuk kebutuhan mendesak suatu negara, kondisi ekstrem, atau penggunaan yang dilakukan untuk kepentingan masyarakat yang tidak digunakan untuk kepentingan komersial.

h. Mengantisipasi dalam hal pelaksanaan paten yang dilakukan oleh pemegang paten atau penerima lisensi dengan cara-cara yang merugikan kepentingan masyarakat. 
i. Untuk memproduksi produk farmasi yang diberi Paten di Indonesia untuk pengobatan pada manusia.

j. Mengimpor pengadaan produk farmasi yang diberi Paten di Indonesia tetapi belum bisa diproduksi di Indonesia guna pengobatan pada manusia.

k. Mengekspor produk farmasi yang diberi Paten dan diproduksi di Indonesia guna pengobatan pada manusia, berdasarkan permintaan dari negara berkembang atau negara yang belum berkembang.

Dari alasan-alasan penerapan lisensi wajib diatas, tentu saja bisa dijadikan sebagai alasan urgensi penerapan lisensi wajib jika benar akan diterapkan pada lisensi paten Vaksin COVID-19. Namun yang perlu diperhatikan disini adalah, suatu negara bisa menjadi pemberi lisensi (licensor) ini apabila inventornya adalah orang atau badan hukum di negara tersebut, kemudian atas permintaan negara berkembang atau negara miskin untuk diekspor invensi tersebut guna mencegah atau mengobati suatu penyakit, yang dalam konteks ini adalah Corona Virus Disease-19 (COVID-19). Kemudian, suatu negara bisa menjadi penerima lisensi (licensee) apabila suatu invensi ditemukan oleh inventor negara lain, dalam hal ini maka pemohon lisensi paten dapat dilakukan oleh pemerintah atau pihak ketiga. Lisensi wajib Vaksin COVID-19 dapat memberikan akses ke negara maju yang lebih mudah dan harga Vaksin COVID-19 menjadi lebih terjangkau.

Seperti yang telah dijelaskan sebelumnya, bahwa vaksin COVID-19 diminta oleh banyak negara berkembang dan negara miskin, diantaranya India dan Afrika Selatan untuk dilakukannya pengabaian hak paten atas Vaksin COVID-19 tersebut, tentu saja hal ini mulanya ditentang oleh negara maju, khususnya negara yang melakukan penemuan ataupun pengembangan terhadap Vaksin COVID-19 maupun termasuk juga negara investor yang sudah mendanai penelitian dalam proses penemuan vaksin. Namun, untuk mendorong kesetaraan akses terhadap vaksin di seluruh dunia dan dalam rangka untuk meningkatkan produksi vaksin global maka sudah sewajarnya apabila hak paten atas Vaksin COVID-19 ini diabaikan untuk jangka waktu tertentu. Hal ini juga sudah diatur dalam Pasal IX Paragraf 3 dan Pasal IX Paragraf 4 Agreement Establishing the World Trade Organization yang pada intinya mengatakan apabila dalam keadaan luar biasa, Konferensi Menteri dapat memutuskan untuk mengesampingkan kewajiban yang dikenakan pada anggota WTO dengan ketentuan bahwa keputusan semacam itu harus diambil dengan tiga per empat anggota kecuali ditentukan lain. Keputusan Konferensi Menteri yang memberikan pengabaian akan menjelaskan terkait dengan pengecualian tersebut beserta keadaan yang membenarkannya, syarat dan ketentuan yang mengatur penerapan pengesampingan, dan tanggal pengesampingan akan berakhir.

Sebagai mana yang telah dijelaskan juga sebelumnya, bagaikan gayung bersambut, keinginan dari negara berkembang maupun negara miskin agar negara kaya untuk membebaskan hak patennya disambut baik dengan didukung oleh pemetintahan Amerika Serikat yakni Biden-Harris, mereka mempertimbangkan bahwa apa yang dihadapi dunia pada saat sekarang ini merupakan krisis kesehatan global dan keadaan luar biasa sehingga membutuhkan tindakan yang luar biasa pula. Dukungan Biden-Haris juga disambut baik oleh Direktur Jenderal World Health Organization (WHO) Dr. Tedros Adhanom Ghebreyesus juga sudah menyampaikan apresiasi kepada komitmen pemerintahan Amerika Serikat untuk mendukung pengabaian sementara atas perlindungan kekayaan intelektual Vaksin COVID-19 sebagai langkah yang berani untuk mengakhiri pandemi secepatnya.

Pemberian perlindungan paten tidak hanya sekedar terkait dengan penanaman modal, tetapi bisa dijadikan posisi tawar menawar suatu perusahaan dalam negara kalau pemerintah tidak menyadari akan hal itu, suatu negara akan mendapatkan kendala atau hambatan dalam melakukan ekspor, terlebih investor akan berpikir dua kali untuk menanamkan modalnya. Sejalan dengan itu, Indonesia yang diketahui mengubah aturan terkait dengan lisensi wajib sebagaimana yang di atur dalam Pasal 20 Undang-Undang 
Nomor 13 Tahun 2016 tentang Paten, perubahan aturan ini dikarenakan adanya kewajiban transfer teknologi yang mewajibkan untuk membuat produk di Indonesia akan menghambat untuk dilakukannya investasi asing, kemudian pertimbangan lainnya adalah karena Pasal 20 tersebut bertentangan dengan Pasal 27 TRIPS dimana pemerintah mengatakan bahwa adanya unsur diskriminasi pada Pasal 20 Undang-Undang Paten sehingga harus dihapuskan. Sebagaimana yang kita ketahui bahwa Pasal 20 ini mewajibkan pamilik hak paten untuk melaksanakan patennya di tanah air atau disebut dengan kebijakan local working. Padahal yang sebenarnya dibicarakan dalam konsel Pasal 27 TRIPS adalah mengenai perbedaan perlakuan antar warga bangsa, dan tidak menyinggung soal alih teknologi dari suatu produk. Berikut ini Pasal 27 TRIPS yang menyebutkan bahwa "Subject to the provisions of paragraphs 2 and 3, patents shall be available for any inventions, whether products or processes, in all fields of technology, provided that they are new, involve an inventive step and are capable of industrial application. Subject to paragraph 4 of Article 65, paragraph 8 of Article 70 and paragraph 3 of this Article, patents shall be available and patent rights enjoyable without discrimination as to the place of invention, the field of technology and whether products are imported or locally produced."

Berikut ini tabel perbandingan antara Pasal 20 Undang-Undang Nomor 13 Tahun 2016 tentang Paten dengan Undang-Undang Nomor 11 Tahun 2020 tentang Cipta Kerja:

\begin{tabular}{|c|c|}
\hline $\begin{array}{c}\text { Undang-Undang Nomor } 13 \text { Tahun } \\
2016 \text { tentang Paten }\end{array}$ & $\begin{array}{c}\text { Undang-Undang Nomor } 11 \\
\text { Tahun } 2020 \text { tentang Cipta } \\
\text { Kerja }\end{array}$ \\
\hline $\begin{array}{l}\text { Pasal 20: } \\
\text { (1) Pemegang wajib membuat } \\
\text { produk atau menggunakan } \\
\text { proses di Indonesia. } \\
\text { (2) Membuat produk atau } \\
\text { menggunakan proses } \\
\text { sebagaimana dimaksud pada } \\
\text { ayat (1) harus menunjang } \\
\text { transfer teknologi, penyerapan } \\
\text { investasi, dan / atau penyediaan } \\
\text { lapangan kerja. }\end{array}$ & $\begin{array}{l}\text { Pasal 107: } \\
\text { Beberapa ketentuan dalam } \\
\text { Undang-Undang Nomor } 13 \\
\text { Tahun } 2016 \text { tentang Paten } \\
\text { diubah sebagai berikut: } \\
\text { Pasal 20 } \\
\text { (1) Paten disib } \\
\text { dilaksanakan } \\
\text { Indonesia. } \\
\text { (2) Pelaksanaan Paten } \\
\text { sebagaimana dimaksud } \\
\text { pada ayat (1), ialah } \\
\text { sebagai berikut: } \\
\text { a. pelaksanaan Paten- } \\
\text { produk yang } \\
\text { meliputi membuat, } \\
\text { mengimpor, atau } \\
\text { melisensikan } \\
\text { produk yang diberi } \\
\text { Paten; } \\
\text { b. pelaksanaan Paten- } \\
\text { proses yang } \\
\text { meliputi membuat, } \\
\text { melisensikan, atau } \\
\text { mengimpor produk } \\
\text { yang dihasilkan } \\
\text { dari proses yang } \\
\text { diberi Paten; atau } \\
\text { c. pelaksanaan Paten- }\end{array}$ \\
\hline
\end{tabular}




\begin{tabular}{|l|l|}
\hline & metode, sistem, \\
dan penggunaan \\
yang meliputi \\
membuat, \\
mengimpor, atau \\
melisensikan \\
produk yang \\
dihasilkan dari \\
metode, sistem, \\
dan penggunaan \\
yang diberi Paten. \\
\hline
\end{tabular}

Pasal terbaru ini dikritisi oleh Prof. Dr. Agus Sardjono, Guru Besar Fakultas Hukum Universitas Indonesia, ia mengatakan bahwa Pasal 20 Undang-Undang Paten merupakan nyawa yang ada dalam Undang-Undang tersebut, dan apabila dihapuskan maka hilang pula makna keseluruhan substansi Undang-Undang Paten. Hal ini dikarenakan bahwa alih teknologi dalam paten merupakan hal yang wajib, dapat dipahami juga secara harafiah kata paten yang berarti terbuka, dan lawan katanya laten yang berarti tertutup, sehingga dalam hal ini konsep keterbukaan dalam paten menghendaki keterbukaan penemuan tersebut. Perlu ditegaskan bahwa paten merupakan pertemuan dari kehendak inventor untuk mengungkap teknologinya, kemudian suatu negara memberikan hak monopoli selama 20 (dua puluh) tahun berdasarkan TRIPS. Sehingga Pasal 20 Undang-Undang Paten ini menjadi kurang relevan apabila diterapkan. Selain itu, local working pada Pasal 20 di peraturan yang lama, dimaknai sebagai aturan domestik yang memungkinkan diberikannya lisensi apabila paten tidak dilaksanakan di negara yang memberikan hak paten. Ketiadaan pengerjaan paten secara domestik bisa dianggap sebagai penyalahgunaan hak paten oleh pemegang hak, yang kemudian bisa dilakukan lisensi wajib sehingga memaksa pemegang hak paten agar patennya itu bisa dieksploitasi proses dan produk yang mendapatkan perlindungan. Perlu dicatat bahwa Pasal 27 TRIPS tidak bisa dibaca letterlijk melainkan harus memperhatikan Pasal 30 dan Pasal 31 TRIPS. Mungkin ada baiknya apabila pemerintah bisa mengelompokkan jenis paten mana saja yang perlu pembatasan, kalau misalnya seperti obat-obatan atau vaksin untuk virus bisa diwajibkan untuk alih teknologi, sebab jika dirahasiakan terus menerus oleh pemegang hak maka ilmuwan lain juga akan kesulitan untuk mengembangkannya. Ditambah misalnya vaksin COVID-19 ini sangat memerlukan alih teknologi karena sangat menyangkut dengan kemaslahatan umat banyak didunia. Sudah seharusnya undang-undang suatu negara menciptakan aturan untuk melindungi masyarakatnya, bukan sebaliknya justru merugikan masyarakatnya sendiri.

Dengan diundangkannya Pasal 20 yang baru, dalam hal pengembangan Vaksin COVID-19, Indonesia sebagai negara berkembang tidak bisa lagi mewajibkan Inventor untuk melaksanakan penemuannya di Indonesia, artinya bahwa tidak akan ada keterbukaan terhadap penemuan tersebut sehingga tidak ada pula transfer teknologi untuk Indonesia dan Indonesia tidak bisa mengembangkan hasil penememuan Inventor dari luar. Dampaknya, Indonesia akan tetap mengimpor dari luar Vaksin COVID-19 ini. Alih-alih memudahkan investor untuk masuk ke Indonesia, namun menambah pekerjaan baru untuk Indonesia sendiri karena tidak bisa mengembangkan penemuan Inventor dan harus menunggu jangka waktu perlindungannya habis barulah bisa dikembangkan penemuannya itu.

\section{KESIMPULAN}

Sesuatu yang dihasilkan melalui proses atau kegiatan manusia seringkali memberikan dampak yang bernilai bagi masyarakat, sehingga nilai sosial tadi menjadi dasar pemberian penghargaan terhadap orang tersebut. Hak ekonomi diberikan perlindungan dalam hak milik, 
sehingga dapat diterjemahkan sebagai pendorong agar si pencipta bersedia untuk membuka karyanya tersebut. Tujuannya dibukanya karya ciptanya tadi adalah untuk memicu penciptaan ide-ide yang baru lagi, oleh kerena itu, melalui keuntungan ekonomi yang didapatkan, seseorang bisa didorong untuk menemukan dan menjual temuannya tadi sehingga bermanfaat untuk masyarakat, namun hak yang diberikan berupa hak milik bisa diberikan terhadap sesuatu apabila memenuhi syarat "enough and as good left in common for others".

Vaksin COVID-19 merupakan komoditi yang harus dilindungi melalui instrumen hukum, sebab vaksin dihasilkan oleh riset yang panjang oleh seorang peneliti sehingga perlu untuk diberikan penghargaan. Peneliti dalam melakukan riset vaksin COVID-19 ini tentu telah mengupayakan waktu, pikiran, tenaga, dan biaya yang tidak sedikit. Selain itu juga, perlindungan vaksin melalui instrumen hukum yang ada juga agar penggunaan maupun penjualan vaksin tersebut dapat dikontrol. Vaksin COVID-19 yang sudah ditemukan oleh inventor akan memberikan hak monopoli dan memberikan insentif untuk secara berkelanjutan juga mengalokasikan dana terhadap riset dan pengembangan terhadap temuannya itu. Selain itu juga, dengan dilindunginya secara hukum penemuan vaksin COVID-19 hasil penemuan inventor akan menciptakan sustainability, yang hingga pada akhirnya menciptakan competitive advantage bagi perusahaan ataupun organisasi yang terlibat di dalamnya.

TRIPS memberikan kemungkinan untuk mengabaikan hak ekslusif dalam perlindungan HKI, artinya bahwa HKI dapat dikecualikan dalam hal tertentu, karena ekslusifitas dalam HKI merupakan hak yang ada batasnya. Salah satu wujud daripada pembatasan hak tersebut adalah adanya aturan mengenai lisensi wajib (compulsory licence). Selain itu, TRIPS, dalam keadaan luar biasa Konferensi Menteri dapat memutuskan untuk mengesampingkan kewajiban yang dikenakan pada anggota WTO. Sehingga, pengabaian sementara hak kekayaan intelektual Vaksin COVID-19 bisa direalisasikan dikarenakan apa yang dihadapi dunia pada saat sekarang ini merupakan krisis kesehatan global dan keadaan luar biasa sehingga membutuhkan tindakan yang luar biasa pula.

\section{DAFTAR PUSTAKA}

\section{BUKU}

(WIPO), World Intellectual Property Organization. The Concept of Intellectual Property. WIPO Publication No. 450E/20 ISBN 978-92-805-3176-3, n.d.

Fahrudin, Adi. Perubahan Sosial Ekonomi di Masa Pandemi Covid-19. Bandung: PT Refika Aditama, 2020.

Granstrand. The Economics and Management of Intellectual Property: Towards Intellectual Capitalism. Cheltenham: Edward Elgar Publishing Limited, 1999.

Krisnani Setyowati, et.al. Hak Kekayaan Intelektual dan Tantangan Implementasinya di Perguruan Tinggi. Bogor: Kantor Hak kekayaan intelektual Institut Pertanian Bogor, 2005.

Maulana, Insan Budi. Sukses Bisnis Melalui Merek, Paten dan Hak Cipta, Bandung: Citra Aditya Bakti, 1997.

Saidin, H.OK. Aspek Hukum Hak Kekayaan Intelektual. Jakarta: Rajawali Pers, 2013.

Sutedi, Adrian. Hak atas Kekayaan Intelektual, Jakarta: Sinar Grafika, 2013

JURNAL

Antariksa, Basuki. "Landasan Filosofis dan Sejarah Perkembangan Perlindungan Hak Kekayaan

Intelektual: Relevansinya bagi Kepentingan Pembangunan di Indonesia." n.d.: 6-8.

Hughes, Justin. "The Philosophy of Intellectual Property." Georgetown Law Journal, 1988.

Ichsan, Achmad Amri. "Analisis Yuridis terhadap Lisensi Wajib dan Pelaksanaan Paten oleh

Pemerintah Berdasarkan Perjanjian TRIP's." Jurnal Ilmu Hukum Legal Opinion Edisi 1 ", Vol 2, 2014.

Syahroni, Irfan Dwi. "Legal Working Paten di Indonesia Berdasarkan TRIPs: Perbandingan India dan Sri Lanka."Journal of Private and Economic Law", Vol.1, No.1, 2021, 1-22.

DOKUMEN INTERNASIONAL 
World Trade Organization, Council for Trade-Related Aspects of Intellectual Property Rights, on paragraph 5, of the Waiver from Certain Provisions of The Trips Agreement for the Prevention, Containment and Treatment of COVID-19, IP/C/W/669, 2 Oktober 2020.

\section{PERATURAN INTERNASIONAL}

Agreement on Trade-Related Aspects of Intellectual Property Rights

Paris Convention for the Protection of Industrial Property

\section{PERATURAN NASIONAL}

Undang-Undang Negara Republik Indonesia Nomor 13 Tahun 2016 tentang Paten.

Undang-Undang Negara Republik Indonesia Nomor 11 Tahun 2020 tentang Cipta Kerja.

\section{INTERNET}

Achmad Reyhan Dwianto, 6 Negara Ini Berlomba-lomba Lakukan Uji Coba Vaksin Corona pada Manusia, <https://health.detik.com/berita-detikhealth/d-4989306/6-negara-iniberlomba-lomba-lakukan-uji-coba-vaksin-corona-pada-manusia>, diakses tanggal 29 April 2021. 6 Negara Ini Berlomba-lomba Lakukan Uji Coba Vaksin Corona pada Manusia. April Jumat, 2020. Achmad Reyhan Dwianto, 6 Negara Ini Berlomba-lomba Lakukan Uji Coba Vaksin Corona pada Manusia, <https://health.detik.com/beritadetikhealth/d-4989306/6-negara-ini-berlomba-lomba-lakukan-uji-coba-vaksin-coronapada-manusia>, diakses tanggal 29 April 2021. (accessed April 29, 2021).

Anwar, Firdaus. Update 5 Jenis Vaksin COVID-19 dan Harganya di Indonesia. Januari Selasa, 2021. https://health.detik.com/berita-detikhealth/d-5349076/update-5-jenis-vaksincovid-19-dan-harganya-di-indonesia (accessed Mei 7, 2021).

Ashutosh Pandey, Negara Kaya Gagalkan Usulan Berbagi Hak Paten Vaksin Corona, $<$ https://www.dw.com/id/negara-kaya-gagalkan-usulan-berbagi-hak-paten-vaksincorona/a-56467124>, diakses tanggal 27 April 2021. Negara Kaya Gagalkan Usulan Berbagi Hak Paten Vaksin Corona diakses tanggal 27 April 2021. Februari Rabu, 2021. https://www.dw.com/id/negara-kaya-gagalkan-usulan-berbagi-hak-patenvaksin-corona/a-56467124 (accessed April 27, 2021).

Basu, Nayanima. WTO to again discuss Covid Vaccine IPR waiver proposal by India, South Africa on Thursday, https://theprint.in/diplomacy/wto-to-again-discuss-covid-vaccineipr-waiver-proposal-by-india-south-africa-on-thursday/642370/, (accessed 9 Mei 2021).

Indonesia, Kongres Advokat. Omnibus Law Dianggap Ciderai Sejarah Paten. Maret Kamis, 2020. https://www.kai.or.id/berita/17102/omnibus-law-dianggap-cederai-sejarahpaten.html (accessed Mei 9, 2021).

Representative, Office of the United States Trade. Statement from Ambassador Katherine Tai on the COVID-19 TRIPS Waiver. Mei Rabu, 2021. https://ustr.gov/about-us/policyoffices/press-office/press-releases/2021/may/statement-ambassador-katherine-taicovid-19-trips-waiver (accessed Mei 9, 2021).

World Health Organization, https://www.who.int/news/item/05-05-2021-who-director-generalcommends-united-states-decisi. WHO Director-General commends United States decision to support temporary waiver on intellectual property rights for COVID-19 vaccines. Mei Rabu, 2021. https://www.who.int/news/item/05-05-2021-who-directorgeneral-commends-united-states-decisi (accessed Maret 9, 2021).

Zuhn, Donald. Biden Administration Supports Waiver of IP Protection for COVID-19 Vaccines. Mei Kamis, 2021. https://www.jdsupra.com/legalnews/biden-administration-supportswaiver-of-8063198/ (accessed Maret 9, 2021). 